\title{
METODE KARYAWISATA DALAM MENINGKATKAN KECERDASAN NATURALIS DI PAUD SPS AN-NABAT KELAS A
}

\author{
Azizah Destarani, Ruly Nadian Sari \\ Pendidikan Guru Madrasah Ibtidaiyah STIT Pringsewu \\ Pringsewu Lampung \\ Alamat: Jalan Raya Wonokriyo Gadingrejo Pringsewu 35373, Telp. 0729-333091 \\ Email:destaraniazizah139@gmail.com, rulynadiansari@gmail.com.
}

\begin{abstract}
One of the intelligences that needs to be developed in early childhood is naturalist intelligence. If naturalist intelligence has been improved early on in children, then many natural damage that occurs today can be minimized. Increasing the naturalist intelligence of children can be started from the school environment and through ways that many children like, namely by tourism. This study uses quantitative data, where data is in the form of numbers and analyzed using statistics. This study uses a survey technique that is taking samples of one population and using observation as a basic data collection tool. The population of this study was the PAUD SPS An-Nabat in the Tanjung Anom Pringsewu area. While the sample was taken 10 students from 18 class A students. The instruments used in this study were questionnaires. From the results of the study, it can be concluded the influence of the independent variable (Trust) on the dependent variable (participation) is $68,7 \%$ with equations $Y=13,680+0,687$. While the rest is influenced by other variables.
\end{abstract}

Keywords: Field trip, naturalist intelligence

\begin{abstract}
Abstrak
Salah satu kecerdasan yang perlu di kembangkan pada anak usia dini yaitu kecerdasan naturalis. Bila kecerdasan naturalis sudah ditingkatkan sejak dini pada anak-anak, maka kerusakan alam yang banyak terjadi saat ini dapat diminimalisir. Meningkatkan kecerdasan naturalis anak dapat dimulai dari lingkungan sekolah dan melalui cara yang banyak disukai anak, yaitu dengan karya wisata. Penelitian ini menggunakan data kuantitatif, dimana data berupa angka dan dianalisis menggunakan statistik. Penelitian ini menggunakan teknik survei yakni mengambil sampel sari satu populasi dan menggunakan observasi sebagai alat pengumpul data yang pokok. Populasi penelitian ini yaitu PAUD SPS An-Nabat yang ada di wilayah Tanjung Anom Pringsewu. Sedangkan sampel di ambil 10 siswa dari 18 siswa kelas A. Instrumen yang digunakan dalam penelitian ini berupa angket. Dari hasil penelitian, dapat disimpulkan bahwa pengaruh variable bebas (Trust) terhadap variable terikat (partisipasi) adalah $68,7 \%$ dengan persamaan $\mathrm{Y}=13,680+0,687$. Sedangkan sisanya dipengaruhi oleh variable lainnya.
\end{abstract}

Kata kunci: Karyawisata, kecerdasan naturalis 


\section{A. PENDAHULUAN}

Pendidikan anak usia dini merupakan jenjang pendidikan yang diselenggarakan sebelum memasuki sekolah dasar. Dalam UU No.23 Tahun 2002 tentang perlindungan anak mengatakan bahwa setiap anak berhak untuk hidup, tumbuh, berkembang, dan berpartisipasi secara wajar sesuai dengan harkat dan martabat kemanusiaan, serta mendapat perlindungan dari kekerasan dan diskriminasi. Salah satunya adalah bahwa setiap anak berhak memperoleh pendidikan dan pengajaran dalam rangka pengembangan pribadinya dan tingkat kecerdasannya sesuai dengan minat dan bakatnya.

Multiple Intelligences yang dalam bahasa Indonesia diterjemahkan sebagai kecerdasan majemuk atau kecerdasan ganda merupakan salah satu teori kecerdasan yang memperoleh banyak pengakuan akhir-akhir ini. Multiple intelegency adalah sebuah penilaian yang melihat secara deskriptif bagamana individu menggunakan kecerdasanya untuk memecahkan masalah dan menghasilkan sesuatu.Kecerdasan pada anak usia dini memiliki peran penting bagi kehidupan di masa mendatang karena anak usia dini merupakan investasi di masa dewasanya kelak. Kecerdasan merupakan tolak ukur pada ketercapaian pada tiap individu tersebut, tetapi kecerdasan bukanlah ajang untuk mengecap orang pintar atau tidaknya, melainkan kecerdasan untuk melihat potensi yang dimiliki seseorang, seperti yang kita ketahui setiap manusia mempunyai potensi yang berbeda-beda.

Sekolah merupakan wahana yang tepat untuk menimba ilmu, oleh sebab itu peran sekolah sangatlah penting, terutaman bagi para pendidik untuk memberikan berbagai ilmu pengetahuan. Karenanya kita sadari bersama bahwa esensi dari kecerdasan naturalis ini sangatah penting, dengan adanya ataupun diberikannya aktivitas mengenai kecerdasan naturalis, maka anak akan menyadari sepenuhnya hakikat memelihara lingkungan sekitar.

Berbagai hasil penelitian menyebutkan bahwa masa usia dini merupakan periode emas bagi perkembangan anak dimana $50 \%$ perkembangan kecerdasan terjadi pada anak usia 0-4 tahun, 30\% berikutnya hingga anak berusia enam tahun. Gardner (Thomas, Armstrong 2002:1-2) mengklasifikasikan ada 9 kecerdasan yang dimiliki oleh manusia, yang terdiri dari: "1) Linguistic Intelligence; 2) Logical Mathematical Intelligence; 3) Spatial Intelligence; 4) Kinestic Intelligence; 5) Musical Intelligence; 6) Interpersonal Intelligence; 7) Intrapersonal Intelligence; 8) Naturalist Intelligence; dan 9)
Existential Intelligence”. Kecerdasan jamak merupakan gambaran untuk para orangtua dan pendidik, bahwa setiap individu mempunyai karakteristik yang berbeda, yang ditampilkan dengan kemampuan yang dimiliki setiap individu berbeda. Masing-masing kecerdasan ini mempunyai indikatorindikator yang harus dicapai, atau standar yang harus dimiliki oleh seseorang yang mampu atau cerdas di bidangnya. Salah satunya adalah kecerdasan naturalis yang berkaitan erat dengan kepekaan dalam mengapresiasikan alam dan lingkungan sekitar.

Kecerdasan naturalis menurut Gardner (2009: 17) adalah kemampuan untuk mengenali, membedakan, mengungkapkan dan membuat kategori terhadap apa yang di jumpai di alam maupun lingkungan. Intinya adalah kemampuan manusia untuk mengenali tanaman, hewan dan bagian lain dari alam semesta. Kecerdasan naturalis adalah kemampuan dalam melakukan kategorisasi dan membuat hierarki terhadap keadaan organisme seperti tumbuhtumbuhan, binatang dan alam.

Perkembangan seorang anak tidak hanya dipengaruhi oleh keturunan tetapi juga lingkungan sekitar. Setiap anak memiliki tingkat kecerdasan yang berbeda-beda, begitu pula dengan kecerdasan naturalis anak. Ada anak yang memiliki kecerdasan naturalis tinggi dan ada yang renda bahkan ada pula yang belum memiliki kecerdasan naturalis oleh sebab itu dalam mengembangkan kecerdasan naturalis seorang anak diperlukan strategi yang tepat sehingga tujuan pembelajaran dapat tercapai dengan baik. Pembelajaran naturalis ditekankan pada pemberian pengalaman langsung untuk mengembangkan kompetensi agar anak mampu melihat dan memahami lingkungan yang ada disekitannya. Anak yang memiliki kecerdasan naturalis yang baik maka ia akan mampu mencintai dan memiliki minat yang tinggi terhadap tumbuhan, hewan dan lingkungan selitar. Pendidikan naturalis diarahkan untuk mencari tahu dan mengambil keputusan yang tepat hingga dapat membantu anak untuk memperoleh pemahaman lebih mendalam tentang diri sendiri dan lingkungan yang ada disekitar, sehingga anak kelak dapat mengembangkan dan menerapkan pemahaman tersebut dalam kehidupan sehari-hari.

Kenyataan dilapangan, peneliti mengamati 10 orang anak, terdiri dari 5 orang anak perempuan dan 5 orang anak laki-laki. Fokus dalam pengamatan ini yakni aspek kecerdasan naturalis "memelihara lingkungan", observasi dilakukan pada subjek dan kelas yang sama. Adapun aktivitas yang dilakukan oleh gurunya yaitu mengajak anak keluar kelas dan berjalan-jalan menuju taman bunga tepatnya 100 
meter dari sekolah. Peneliti mengamati bahwa hanya 4 orang anak dari 10 orang anak pada kelas A yang ikut dalam kegiatan membersihkan sampah serta mencabut rumput, yang lain hanya bermain-main dengan temannya dan berlari-lari kesana kemari, bahkan ada yang menginjak tanaman dan mengkibaskibaskan tangannya ke tanaman.

Moeslichatoen (2004: 68) mengatakan kunjungan lapangan atau karyawisata merupakan salah satu metode melaksanakan kegiatan pengajaran di taman kanak-kanak dengan cara mengamati dunia sesuai dengan kenyataan yang ada secara langsung yang meliputi manusia, hewan, tumbuh-tumbuhan, dan benda-benda lainnya.

Selama ini yang berkembang dimasyarakat, hanya kecerdasan matematika saja, anak yang pintar adalah anak yang cerdas di logika matematika, sehingga kecerdasan yang lainnya terabaikan, atau dianggap tidak penting. Hal ini dikarenakan belum adanya pengetahuan tentang kecerdasan jamak, termasuk salah satunya kecerdasan naturalis, padahal kecerdasan naturalis merupakan bagian tak bisa dipisahkan dari kehidupan sekitar kita.

Tabel.1 Indikator Kecerdasan Naturalis

\begin{tabular}{|c|l|c|c|c|}
\hline No & \multicolumn{1}{|c|}{ Indikator } & Ya & Tidak & Keterangan \\
\hline 1 & $\begin{array}{l}\text { Menjaga } \\
\text { lingkungan }\end{array}$ & & $\sqrt{ }$ & $\begin{array}{c}\text { Masih } \\
\text { membuang } \\
\text { sampah } \\
\text { sembarangan }\end{array}$ \\
\hline 2 & $\begin{array}{l}\text { Memelihara } \\
\text { binatang }\end{array}$ & $\sqrt{ }$ & $\begin{array}{l}\text { Baru satu } \\
\text { atau dua } \\
\text { orang }\end{array}$ \\
\hline 3 & $\begin{array}{l}\text { Merawat } \\
\text { tumbuhan }\end{array}$ & & $\sqrt{ }$ & Belum \\
\hline 4 & $\begin{array}{l}\text { Suka } \\
\text { mempelajari } \\
\text { siklus flora } \\
\text { dan fauna }\end{array}$ & & $\sqrt{ }$ & $\begin{array}{c}\text { Tidak } \\
\text { sebagian }\end{array}$ \\
\hline 5 & $\begin{array}{l}\text { Mengetahui } \\
\text { perubahan } \\
\text { cuaca }\end{array}$ & $\sqrt{ }$ & $\begin{array}{c}\text { Tidak } \\
\text { sebagian }\end{array}$ \\
\hline
\end{tabular}

Berdasarkan tabel di atas menunjukan bahwa kecerdasan naturalis masih tergolong rendah. Hal ini di dapatkan dari hasil observasi di PAUD SPS AnNabat Tanjung Anom sehingga peneliti merasa bahwa penelitian ini sangat penting untuk dilakukan guna mendapatkan hasil yang lebih baik.

\section{B. TUJUAN}

Tujuan penelitian ini adalah untuk mengetahui pengaruh metode karyawisata dalam meningkatkan kecerdasan naturalis Anak Usia Dini di PAUD SPS An-Nabat Desa Tanjung Anom Kecamatan Ambarawa Kabupaten Prinsewu TA 2018/2019.

\section{METODE PENELITIAN}

Penelitian tentang metode karyawisata dalam meningkatkan kecerdasan naturalis ini menggunakan pendekatan penelitian kuantitatif, dimana data berupa angka dan dianalisis menggunakan statistik.

Tabel.2 Model Summaryb

\begin{tabular}{|l|r|r|r|r|r|}
\hline $\begin{array}{l}\text { Mod } \\
\text { el }\end{array}$ & \multicolumn{1}{|c|}{$\mathrm{R}$} & Square & $\begin{array}{r}\text { Adjusted } \\
\text { R Square }\end{array}$ & $\begin{array}{c}\text { Std. Error } \\
\text { of the } \\
\text { Estimate }\end{array}$ & $\begin{array}{c}\text { Durbin- } \\
\text { Watson }\end{array}$ \\
\hline 1 & $.833^{\mathrm{a}}$ & .693 & .655 & .927 & 2.184 \\
\hline
\end{tabular}

a. Dependent Variable: kecerdasan

Output bagian (Model Summary) tabel di atas dapat dijelaskan besarnya korelasi/ hubungan ( $\mathrm{R}$ ) yaitu sebesar 0.883 dan dijelaskan besarnya presentase pengaruh variable bebas terhadap variable terikat yang disebut koefisien determinasi yang merupakan hasil dari penguadratan R. Dari output tersebut diperoleh koefisien determinasi (R2) sebesar 0.833 yang mengandung pengertian bahwa pengaruh variable bebas (Trust) terhadap variable terikat (partisipasi) adalah 69,3\%. Sedangkan sisanya dipengaruhi oleh variable lainnya.

Penelitian ini menggunakan teknik survei yakni mengambil sampel dari satu populasi dan menggunakan wawancara dan observasi sebagai alat pengumpul data yang pokok. Populasi penelitian ini yaitu PAUD SPS An-Nabat yang ada di wilayah Tanjung Anom Pringsewu. Sedangkan sampel di ambil 10 siswa dari 18 siswa kelas A. Instrumen yang digunakan dalam penelitian ini berupa angket dan observasi.

Penelitian ini menggunakan uji analisis regresi linier sederhana. Uji regression digunakan untuk mengukur besarnya pengaruh satu variabel bebas atau variabel independent atau variabel predicton atau variabel $\mathrm{x}$ terhadap variabel tergantung atau variabel dependent atau variabel terikat atau variabel y. Adapun syarat 
kelayakan yang harus terpenuhi saat menggunakan regresi linier sederhana adalah:

1 Jumlah sample yang digunakan harus sama.

2 Jumlah variabel bebas (x) adalah 1 (satu).

3 Nilai residual harus berdistribusi normal.

Terdapat hubungan yang linier antara variabel bebas (x) dengan variabel tergantung $(\mathrm{y})$.

4 Tidak terjadi gejala heteroskedastisitas.

5 Tidak terjadi gejala autoporalasi (untuk data timerais)

\section{HASIL DAN PEMBAHASAN}

Tahap pertama yang dilakukan pada penelitian ini adalah pengsian angket yang di lakukan oleh guru dengan menyanyakan satu per satu responden, untuk mengetahui pengaruh karyawisata terhadap kecerdasan naturalis anak. Setelah diperoleh data, 10 responden tersebut langsung diobservasi bagaimana interaksi sosialnya. Berdasarkan hasil penelitian ini, maka peneliti mengambil uji regression pada menginput data di SPSS, yang dimana uji regression ini adalah model regression linier dengan melibatkan lebih dari satu variabel atau predicator.

Secara umum rumus persamaan regresi linier sederhana adalah $y=a+b x$. Sementara untuk mengetahui nilai koefisien regresi tersebut data dapat berpedoman pada output yang berada pada tabel koefisien sebagai berikut:

Tabel.3 Coefficients ${ }^{\mathrm{a}}$

\begin{tabular}{|c|c|c|c|c|c|}
\hline \multirow[b]{2}{*}{ Model } & \multicolumn{2}{|c|}{$\begin{array}{c}\text { Unstandardized } \\
\text { Coefficients }\end{array}$} & $\begin{array}{c}\text { Standar } \\
\text { dized } \\
\text { Coeffici } \\
\text { ents }\end{array}$ & & \\
\hline & $B$ & $\begin{array}{l}\text { Std. } \\
\text { Error }\end{array}$ & Beta & $\mathrm{t}$ & Sig. \\
\hline $\begin{array}{ll}1 & \text { (Const } \\
& \text { ant) }\end{array}$ & 13.860 & 1.153 & & $\begin{array}{r}12.0 \\
20\end{array}$ & .000 \\
\hline $\begin{array}{l}\text { karyaw } \\
\text { isata }\end{array}$ & .687 & .162 & .833 & $\begin{array}{r}4.25 \\
0\end{array}$ & .003 \\
\hline
\end{tabular}

a. Dependent Variable:

kecerdasan a=angka konstanta dari unstan dan dized cooeffiesients. Dalam kasus nilainya adalah sebesar 13, 860. Angka ini merupakan angka konstanta yang mempunyai arti bahwa jika tidak ada karyawisata (x) maka nilai konstanta kecerdasan naturalis (y) adalah 13,860 .

$\mathrm{b}=$ angka koofisien regresi. Nilainya sebesar 687 . Angka ini mengandung arti bahwa setiap penambahan $1 \%$ tingkat karyawisata (x) maka kecerdasan naturalis akan meningkat sebesar 687 . Karena nilai koofisien regresi bernilai minus (-). Maka dengan demikian dapat dikatakan bahwa karyawisata (x) berpengaruh positif terhadap kecerdasan naturalis (y). Sehingga persamaan regresinya adalah:

$Y=13,860+0,687$

Berdasarkan uraian diatas dapat dijelaskan bahwa kegiatan karyawisata mempengaruhi kecerdasan naturalis anak kelas A PAUD SPS An-Nabat Desa Tanjung Anom Kecamatan Ambarawa Kabupaten Prinsewu TA 2018/2019.

\section{E. PENUTUP}

1. Kesimpulan

Sesuai dengan perumusan masalah yang di ajukan dan berdasarkan hasil analisis pembahasan, maka kesimpulan penelitian ini adalah: Proses pembelajaran melalui kegiatan karyawisata meliputi tahap pembukaan atau awal, tahap inti dan tahap akhir atau penutup. Kegiatan awal bertujuan untuk memberikan pengantar atau persepsi awal mengenai kegiatan yang akan dilakukan pada kegiatan inti. Kegiatan inti merupakan serangkaian proses pembelajaran melalui karyawisata yang dilakukan anak, yang dapat dikaitkan dengan tema pembelajaran yang sedang berjalan. Kegiatan penutup bertujuan untuk mereview atau mengulas kembali kegiatan yang telah dilakukan yang dikaitkan dengan tema maupun aspek-aspek kecerdasan naturalis. Kegiatan karyawisata dilakukan dengan mengunjungi tempat-tempat yang berbeda guna menunjang aktivitas dari aspek-aspek kecerdasan naturalis, seperti kebun binatang, pantai, taman, dan tmpat-tempat wisata alam lainnya dengan di tunjang media lainya seperti media gambar dan alat yaitu kaca pembesar. 
Karyawisata dapat meningkatkan kecerdasan naturalis anak PAUD SPS AN-Nabat, dapat menghadirkan suasana belajar yang berbeda darisebelumnya dimana anak-anak mampu mengenal langsung objek yang akan dikunjungi, anak-anak akan melihat dan mengeksplore yang ada dilingkungannya, berimajinasi yang berkaitan dengan aspek-aspek kecerdasan naturalis yaitu aspek tumbuhan, hewan dan benda-benda mati berdasarkan olah data:

a=angka konstanta dari unstan dan dized cooeffiesients. Dalam kasus nilainya adalah sebesar 13, 860. Angka ini merupakan angka konstanta yang mempunyai arti bahwa jika tidak ada karyawisata (x) maka nilai konstanta kecerdasan naturalis (y) adalah 13,860 .

$\mathrm{b}=$ angka koofisien regresi. Nilainya sebesar 0,687 . Angka ini mengandung arti bahwa setiap penambahan $1 \%$ tingkat karyawisata (x) maka kecerdasan naturalis akan meningkat sebesar 687. Karena nilai koofisien regresi bernilai minus (-). Maka dengan demikian dapat dikatakan bahwa karyawisata (x) berpengaruh positif terhadap kecerdasan naturalis $(\mathrm{y})$.

\section{Saran}

Berdasarkan kesimpulan di atas, ada beberapa saran yang dapat diberikan sebagai berikut :

1 Bagi Guru

Guru dapat menggunakan metode pembelajaran berbasis pembelajaran kontekstual sebagai salah satu bentuk pembelajaran yang dapat membantu mengatasi permasalahan rendahnya kecerdasan naturalis anak.

2 Bagi Peneliti Lain

a. Penggunaan pembelajaran kontekstual dalam meningkatkan kecerdasan naturalis anak dapat diterapkan lebih beragam media dan perlakuannya sehingga tujuan pembelajaran tercapai secara maksimal.

b. Penggunaan pembelajaran kontekstual memberikan hasil dalam meningkatkan kecerdasan naturalis anak. Sehingga metode pembelajaran ini dapat diterapkan untuk meningkatkan perkembangan variable lain.

\section{DAFTAR PUSTAKA}

Armstrong, Thomas, 2002, Setiap Anak Cerdas: Panduan Membantu Anak Belajar dengan Memanfaatkan Multiple Intelligencenya, (alih bahasa: Buntaran, R), PT Gramedia Pustaka Utama, Jakarta.

Campbell Linda, Campbell Bruce, dan Campbell Dee, 2007, Metode Praktis Pembelajaran berbasis Mutiple Intelligences, Intuisi Press, Jakarta.

Gusti Ngurah Agung, 2011, Manajemen Kepenulisan, Rjawali Press, Jakarta.

Hadeli, 2006, Metode Penelitian Kependidikan, Ciputat Press, Jakarta.

Jamaris, Martini, 2010, Orientasi Baru Dalam Psikologi Pendidikan, Alfabeta, Jakarta.

Muhammad dan Wiyani, Novan Ardy, 2012, Psikologi Pendidikan, Ar-Ruzz Media, Jogjakarta.

Mukhtar Latif, Zukhairina, Rita Zubaidah, dan M Afandi, 2013, Orientasi Baru Pendidikan Anak Usia Dini, Kencana Prenada Media Group, Jakarta.

Moeslichatoen, 2000, Metode Pengajaran, Rineka Cipta, Jakarta.

Musfiroh, Tadkirotun, 2009, Pengembangan Kecerdasan Majemuk, Universitas terbuka, Jakarta.

Prof.Sukardi,Ph.D, 2003, Metodologi Penelitian, PT Bumi Aksara, Jakarta.

Yaumi, Muhammad, 2012, Pembelajaran Berbasis Multiple Intelligences, Dian Rakyat, Jakarta.

Roestiyah, 2008, Strategi Belajar Mengajar, Rineka Cipta, Jakarta.

Siantayani, Yulianti, 2011, Persiapan Membaca Bagi Balita, Kritzer publisher, Sleman Yogyakarta.

Yaumi, Muhammad dan Ibrahim Nurdin, 2011, Kecerdasan jamak (multiple Intelligences), kencana, Jakarta.

Yaumi, Muhammad dan Damopolii, Muljiono, 2014, Action Research Teori, Model, Dan Aplikasi, Kencana, Jakarta. 
